\title{
Clinical characterization, disability, and mortality in people with strokes during 90 days
}

\author{
Caracterização clínica, incapacidade e mortalidade de pessoas com acidente vascular cerebral isquêmico em 90 dias
}

Caracterización clínica, discapacidad y mortalidad de personas con accidente cerebrovascular isquémico en 90 días

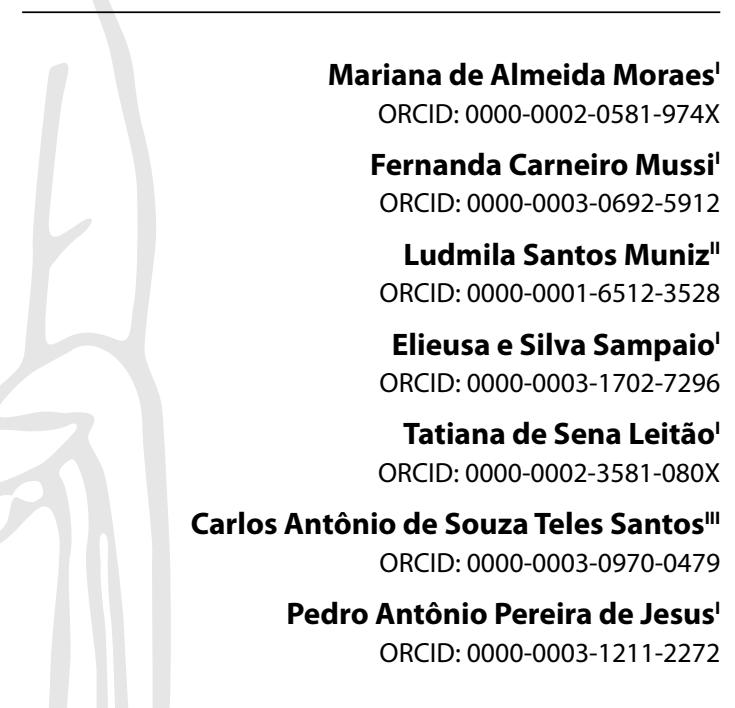

'Universidade Federal da Bahia. Salvador, Bahia, Brazil. "Hospital Geral Roberto Santos. Salvador, Bahia, Brazil. "'Centro de Pesquisas Gonçalo Moniz. Salvador, Bahia, Brazil.

How to cite this article:

Moraes MA, Mussi FC, Muniz LS, Sampaio ES, Leitão TS, Teles CAS, et al. Clinical characterization, disability, and mortality in people with strokes during 90 days. Rev Bras Enferm. 2022;75(2):e20201383. https://doi.org/10.1590/0034-7167-2020-1383

\section{Corresponding author:}

Mariana de Almeida Moraes

E-mail:mariana.gibaut@ufba.br

EDITOR IN CHIEF: Antonio José de Almeida Filho ASSOCIATE EDITOR: Ana Fátima Fernandes

Submission: $02-01-2021$

Approval: 05-24-2021

\section{ABSTRACT}

Objectives: to describe clinical characteristics and mortality of people with ischemic cerebrovascular accidents (strokes); to compare disability before the event and 90 days after. Methods: longitudinal study with 308 people hospitalized in Salvador-BA. Data collection took place from 03/2019 to 01/2020. Descriptive and inferential statistics were used. Results: mean age was 64.8 years, and National Institute of Health Stroke Scale score was 10.7. The median length of stay in the hospital was 11 days. Afro-descendants predominated (84\%), elementary educational level (68.4\%), income up to three minimum wages (89.1\%), arrival within 4.5 hours of symptoms ( $57.9 \%$ ) and admission to a specialized unit (71.8\%). Prevalence of thrombolysis: $26 \%$. The asymptomatic before the event category predominated $(85.3 \%)$ as did the moderate/severe disability (41.5\%) after 90 days. $19.7 \%$ of the sample evolved to death. Conclusions: the high mortality and disability generated by the event have implications for health management and care.

Descriptors: Stroke; Statistics on Sequelae and Disability; Epidemiology; Disease Prevention; Nursing.

\section{RESUMO}

Objetivos: descrever características clínicas e a mortalidade de pessoas com acidente vascular cerebral isquêmico; comparar a incapacidade antes do evento e 90 dias depois. Métodos: estudo longitudinal, com 308 pessoas hospitalizadas em Salvador-BA. A coleta de dados ocorreu de 03/2019 a 01/2020. Empregou-se estatística descritiva e inferencial. Resultados: a média de idade foi de 64,8 anos $(\mathrm{dp}=14,1)$ e a pontuação da National Institute of Health Stroke Scale foi 10,7 (dp=7,2). A mediana do tempo de internação foi de 11 dias. Predominaram negros $(84,0 \%)$, escolaridade até o fundamental $(68,4 \%)$, renda até três salários mínimos $(89,1 \%)$, chegada até 4,5 horas do início dos sintomas $(57,9 \%)$ e internação em unidade especializada $(71,8 \%)$. Realizaram trombólise: $26,0 \%$. Predominou a categoria assintomática $(85,3 \%)$ antes do evento e incapacidade moderada/severa (41,5\%) após 90 dias $(p=0.117$ ). Óbito atingiu $19,7 \%$ da amostra. Conclusões: $a$ alta mortalidade e incapacidade geradas pelo evento têm implicações para a gestão e cuidado em saúde.

Descritores: Acidente Vascular Cerebral; Estatísticas de Sequelas e Incapacidade; Epidemiologia Prevenção de Doenças; Enfermagem.

\section{RESUMEN}

Objetivos: describir características clínicas y la mortalidad de personas con accidente cerebrovascular isquémico; comparar la discapacidad antes del evento y 90 días después. Métodos: estudio longitudinal, con 308 personas hospitalizadas en Salvador-BA. Recolecta de datos ocurrió de 03/2019 a 01/2020. Empleado estadística descriptiva e inferencial. Resultados: la mediana de edad fue de 64,8 años, y la puntuación de la National Institute of Health Stroke Scale fue 10,7. La mediana del tiempo de internación fue de 11 días. Predominaron negros $(84 \%)$, hasta la educación primaria $(68,4 \%)$, renta hasta tres salarios mínimos $(89,1 \%)$, llegada hasta 4,5 horas del inicio de los síntomas $(57,9 \%)$ e internación en unidad especializada $(71,8 \%)$. Realizaron trombolisis: $26 \%$. Predominó la categoría asintomática $(85,3 \%)$ antes del evento y discapacidad moderada/severa (41,5\%) tras 90 días. Óbito alcanzó 19,7\% de la muestra. Conclusiones: la alta mortalidad y discapacidad generadas por el evento hay implicaciones a la gestión y cuidado en salud.

Descriptores: Accidente Cerebrovascular; Estadísticas de Secuelas y Discapacidad; Epidemiología; Prevención de Enfermedades; Enfermería. 


\section{INTRODUCTION}

The cerebrovascular accident (CVA), also known as a stroke, is the second most prevalent neurological disease and the second leading cause of mortality in the world ${ }^{(1)}$, with the ischemic event (iCVA) being responsible for $70 \%$ to $80 \%$ of cases, while hemorrhagic ones answer for $20 \%$ to $30 \%$. In Brazil, it is the second leading cause of death in adults ${ }^{(2)}$, with a mortality rate of $10 \%$ in the first 30 days after CVA, reaching $40 \%$ at the end of the first year ${ }^{(3)}$.

Despite the decrease in cases and stroke mortality rate per 100.000 inhabitants in recent years ${ }^{(2)}$, this reduction has been uneven between different regions of the country and dependent of characteristics such as sex and age $\mathrm{e}^{(3-6)}$. It is noteworthy that the highest incidence and mortality rates occur in regions with less economic development - such as the Northeast region ${ }^{(7)}$.

In addition to the high mortality rate, most people who survive the acute phase of strokes have neurological disability that requires rehabilitation ${ }^{(8)}$, and approximately $40 \%$ have to retire early ${ }^{(2)}$. These facts generate high individual and social costs ${ }^{(3)}$.

This epidemiological panorama highlights the need for actions to prevent and control risk factors for the cerebrovascular event and for interventions that optimize quick access to effective treatment so that people can enjoy the benefits of reperfusion therapies ${ }^{(9)}$. Therefore, it is important to know a set of variables that reveal: the risk factors for the occurrence of a cerebrovascular event ${ }^{(10-12) ;}$; the social, economic and demographic characteristics that can influence the early recognition of the event ${ }^{(13)}$; the immediate actions of the victims and people around them in face of its manifestation; and access to treatment.

It is noteworthy that the benefits of stroke therapies are timedependent and can take advantage of the quick arrival of the individual at an adequate health service. Studies have shown that the impact of stroke-related morbidity and mortality can be minimized with the early infusion of thrombolytics within 4.5 hours of symptom onset ${ }^{(3,9)}$. However, benefits are also greater when the appropriate therapeutic management starts early, which includes etiological investigation, early rehabilitation and clinical stability, prescription of appropriate drugs according to the etiology of stroke and hospitalization in stroke units ${ }^{(4,6)}$.

Therefore, it is equally necessary to know the access to reperfusion therapies in stroke and the specialized units capable of reducing disability and mortality ${ }^{(3,14-15)}$. Given the high rate of disability resulting from the event, it is also important to know the degree of disability of the people affected, aiming, in addition, to improving primary prevention, to focus on appropriate acute care and rehabilitation actions.

Despite advances in knowledge regarding epidemiology, etiology, risk factors and treatment, information on the relation between these factors and on life after stroke is still limited ${ }^{(16)}$. Authors highlight the scarcity of epidemiological and health care studies on this event in Latin American countries, such as Brazil. Therefore, research on prevention, incidence, prevalence, results, acute treatment and rehabilitation is recommended, with emphasis on those aimed at improving prevention and prognosis ${ }^{(17)}$.

In the Northeast region, especially in the state of Bahia, there is a lack of studies related to the epidemiological characterization of people who suffered a stroke. Based on a literature survey recently carried out, a study in the state was identified that recorded data from 166.883 emergency admissions in Salvador. This study observed that diseases of the circulatory system had a higher incidence (3.5 individuals/thousand inhabitants) and represented a higher proportion of hospitalizations (31.4\%), higher hospitalization time (17 days \pm 5 days), higher care costs ( $R \$ 1.967,61 \pm R \$ 620,7)$, and a mortality rate of $10 \%$. Among the circulatory system diseases, the main etiology was stroke $(20.7 \%)^{(5)}$. Other studies carried out in the state of Bahia with people who suffered strokes are relevant, but they focused their investigations on potential predictors for community integration after the event ${ }^{(16)}$, on the validation of a hospital mobility scale ${ }^{(18)}$ and on the proposal of a new predictive scale of falls for people who have suffered a stroke ${ }^{(19)}$.

Therefore, there are few records on the sociodemographic and clinical variables in people with CVA in the state, and these variables may have specificities due to the culture, income level and education of the population, race/color and characteristics of the pre-hospital and in-hospital care network ${ }^{(3)}$. There is also limited documentation on the degree of disability of people with strokes in the state of Bahia. This restriction determines the need for support from health services and professionals, as well as the training of the patient and the people involved in their home care.

Based on the above, knowing the profile of people with CVA hospitalized in a reference hospital in Salvador, Bahia, the only one with a level III CVA unit certified by the Ministry of Health in the capital, can significantly contribute to the creation of strategies of nursing health education aimed at preventing the event with a focus on modifiable risk factors. This has the ability to reduce the clinical, social, and economic impact that the disease causes in this state.

The findings of this study can also guide managers in structuring and offering services aimed at caring for people with strokes, by revealing possible gaps in the health system. Also, they can highlight the necessary support to be offered for inhospital care and treatment, and highlight the need for nursing care in home rehabilitation considering the degree of disability of the affected people.

\section{OBJECTIVES}

To describe clinical characteristics and mortality of people with ischemic cerebrovascular accidents; to compare disability before the event and 90 days after.

\section{METHODS}

\section{Ethical aspects}

This study is part of the bigger project named "Factors associated with disability and mortality due to ischemic stroke and the treatment access periods". This project was approved by the Research Ethics Committee, respecting the ethical principles of Resolutions 466/12 and 580/18 from the National Health Council $^{(20-21)}$. Participants were guaranteed clarification of the research objectives and the content of the Free and Informed Consent Form, personal secrecy, privacy, and the right to withdraw from the research at any stage, without causing them harm. 


\section{Study design and location}

Observational and longitudinal study carried out in the largest hospital in the state of Bahia, with 640 hospital beds, classified as a tertiary complex teaching hospital. It is certified by the Ministries of Health and Education, as a level III High Complexity Reference Center in Neurology, for people with strokes ${ }^{(22)}$. It has a Stroke Comprehensive Care Unit (UAVC), an Emergency Unit, a Neurology ward, a Neurosurgery ward, a Vascular Surgery ward, and a Neurosurgical Intensive Care Unit. In addition, it has three Intensive Care Units (General A, B and surgical) and a Medical Clinic Ward. Ideally, all people with CVA in the acute phase should be admitted to the UAVC. However, given the insufficient number of hospital beds or the seriousness of the clinical condition, they may stay in other of the units. Therefore, all units were visited to select the participants.

The theoretical reference used for this study was the STROBE (Strengthening the Reporting of Observational Studies in Epidemiology ${ }^{(23)}$, following the guidelines of this tool from the preparation of the abstract to the discussion.

\section{Sample, criteria of inclusion and exclusion, and period}

Convenience sampling was used, and the population consisted of 320 people hospitalized at the investigation site from March to October 2019, with a medical diagnosis of CVA. The inclusion criteria were: having an acute stroke confirmed in the medical record; and being at least 18 years old. Exclusion criteria were: having had the stroke (time of onset of stroke symptoms) more than 10 days ago, due to the possibility of recall bias; and presenting symptoms that impeded verbal communication coupled with the lack of companions to answer the questions.

\section{Study protocol}

\section{Data Collection Instruments}

Three instruments were used for data collection.

One instrument was used to collect sociodemographic and clinical characterization data and consisted of multiple-choice and semi-structured questions. The sociodemographic variables surveyed were age, sex, self-reported race/color, marital status, education, monthly family income, employment status and city of residence. Regarding the clinical characterization data, the following variables were collected: signs and symptoms at the time of stroke; date and time of onset of signs and symptoms or occurrence of Wake-Up Stroke (time when the person wakes up and notices the deficit or is identified with signs and symptoms of stroke by someone); presence of atrial fibrillation (AF); diabetes mellitus (DM); systemic arterial hypertension (SAH); dyslipidemia; previous stroke and/or acute myocardial infarction (AMI); smoking; family history of stroke; previous visits in health services before admission to the hospital of reference in neurology; admission to the CVA Unit at the study site and time of arrival there; if thrombolysis was performed; Premorbid Rankin; and the outcomes of discharge, death or transfer. The time of arrival at the referral hospital was obtained by adding up the hours from the onset of symptoms or their recognition until arrival at the studies units. Another clinical variable raised was the National Institute of Health Stroke Scale (NIHSS) score. It should be noted that the NIHSS is a scale based on 11 items of the neurological examination commonly affected by stroke, including: level of consciousness, eye movement, visual field, facial paralysis, arm motor activity, leg motor activity, limb ataxia, sensitivity, language, dysarthria, and extinction. It allows evaluating both the severity and the magnitude of the neurological deficit. The total score can reach values from 0 to 42 points, indicating that the higher the value, the greater the severity of the stroke and neurological deficit ${ }^{(24)}$.

Another instrument used was the Rankin Scale (RS), a version translated and culturally adapted for Brazil and validated for application by telephone ${ }^{(25)}$ to assess functional disability and mortality from stroke. The scale measures the individual's ability to perform activities of daily living based on the assessment of global disability and care needs to perform instrumental and basic activities of daily living with an emphasis on motor impairment. According to the score obtained, the individual can be classified from 0 to 5:0 - no disability; 1 - no significant disability; 2 - mild disability; 3 - moderate disability; 4 - moderately severe disability; and 5 - severe disability. Grade 6 is also included, which corresponds to death ${ }^{(25)}$. This scale was applied to verify previous functional incapacity, and the premorbid Rankin was measured.

The Telephone Call Protocol was also used, 90 days after the event, to standardize the approach to telephone calls. It was composed of items to record the identification of participants, the occurrence or not of death, confirmation of the presence of disability prior to stroke and the score obtained by applying the RE.

\section{Data Collection Procedures}

The data collection team consisted of a doctoral student, a master's student, and six undergraduate nursing students, who were trained and supervised by the doctoral student to carry out the screening of eligible patients and for the operationalization of data collection. The instrument was pre-tested with five people with CVA, in February 2019, to assess its applicability and make the necessary adjustments. These people were not part of the sample.

Data collection took place in three phases. Phase I was from March to October 2019 and corresponded to the identification of eligible participants in the Emergency Units, UAVC, Neurology, Internal Medicine, Neurosurgery, Vascular Surgery, and Intensive Care Units. Once identified, they received an explanation about the objectives and importance of the study and were invited to participate. After acceptance, they were instructed and signed the consent form. In this phase, the functional capacity prior to the CVA was questioned, based on the Rankin Scale items. The instrument was also applied to collect sociodemographic and clinical data, except regarding the NIHSS at admission, the date and time of arrival at the study site, the presence of AF, DM, SAH, dyslipidemia and thrombolysis procedure that were obtained in the medical records. In situations where the eligible participant did not have clinical, cognitive and/or emotional conditions to interact with the researcher, the approach was made with his/ her companion. 
Phase Il started in March 2019 and lasted until January 2020. It was carried out to monitor the participants throughout their hospital stay to identify the inpatient units visited at the study site and the length of stay until hospital discharge, transfer, or death. In this phase, some clinical data, when not identified in Phase I, were obtained from the medical records. All previously mentioned units were visited daily for the proper follow-up of the participants.

Phase III took place from June 2019 to January 2020. It consisted of monitoring the participants 90 days after the CVA, when they were contacted by telephone, following the standardized connection protocol, for the application of the RE or the possible identification of the occurrence of death. During this period, the stabilization of the clinical and functional status is expected and thus enables the assessment of outcomes. The RE was answered by the participant or, when this was not possible, by his companion during home care.

\section{Analysis of results and statistics}

The data composed a database in SPSS (version 22.0) and were analyzed in this software. Age and NIHSS score were analyzed through mean and standard deviation. All other variables were analyzed regarding relative and absolute frequencies. To compare the Rankin before and up to 90 days, we grouped them into classes: 0 - Asymptomatic; 1 to 2 - no significant to mild disability; 3 to 4 - moderate to moderately severe disability; 5 - severe disability; and 6 - death. To compare the Rankin prior to stroke and the Rankin 90 days after the onset of symptoms, the Trend chi-square test was used, adopting a statistical significance of $5 \%$.

\section{RESULTS}

Of the 320 people hospitalized during the research period, 12 were excluded because they had a stroke more than 10 days prior, or for having symptoms that impeded verbal communication and no companion to answer the research questions. Thus, the sample consisted of 308 participants.

Considering that disability was assessed 90 days after the event, nine participants could not be contacted by phone calls. Therefore, this variable considered 299 participants.

As for sociodemographic characteristics, the sample consisted of $50 \%$ women, with a mean age of 64.8 years $(S D=14.11)$. The minimum age was 21 years, and the maximum was 97, with the predominance of individuals aged 60 years-old or older (68.5\%). As for the self-declared race/color, brown and black people accounted for $84 \%$ of the sample. The majority had no partner (53.4\%), studied up to elementary school (68.4\%), had an inactive employment status (63.5\%), had a monthly family income of up to three minimum wages (89.1\%), and resided in Salvador, Bahia (80.5\%).

As for comorbidities, $78.9 \%$ of the sample had systemic arterial hypertension; $31.4 \%$, dyslipidemia; $28.7 \%$, diabetes mellitus; and $11 \%$, atrial fibrillation. About previous cardiovascular events, $34.2 \%$ reported stroke; and $11.1 \%$, AMI. Almost a third of the sample $(31.8 \%)$ reported a history of stroke in first-degree relatives, and $41.6 \%$ were smokers or had been smokers.
Table 1 - Sociodemographic characterization of participants, Salvador, Bahia, Brazil, 2020

\begin{tabular}{|c|c|c|}
\hline Variables & $\mathbf{n}$ & $\%$ \\
\hline \multicolumn{3}{|l|}{ Age group $(\mathrm{n}=308 ;$ mean $=64.8$ years; $S D=14.11)$} \\
\hline 21 to $<40$ years & 19 & 6.2 \\
\hline 40 to $<60$ years & 78 & 25.3 \\
\hline 60 to $<80$ years & 164 & 53.2 \\
\hline More than or equal to 80 years & 47 & 15.3 \\
\hline \multicolumn{3}{|l|}{ Gender $(n=308)$} \\
\hline Male & 154 & 50.0 \\
\hline Female & 154 & 50.0 \\
\hline \multicolumn{3}{|l|}{ Self-declared race/color $(n=307)$} \\
\hline Others (yellow, indigenous) & 3 & 2.0 \\
\hline White & 46 & 15.0 \\
\hline Black & 109 & 35.5 \\
\hline Brown & 149 & 48.5 \\
\hline \multicolumn{3}{|l|}{ Marital status $(\mathrm{n}=307)$} \\
\hline With companion (married or in a relationship) & 143 & 46.6 \\
\hline Without companion (single, widow or divorced) & 164 & 53.4 \\
\hline \multicolumn{3}{|l|}{ Educational level $(n=304)$} \\
\hline Illiterate/signs name & 61 & 20.1 \\
\hline Elementary school complete or incomplete & 147 & 48.3 \\
\hline High school complete or incomplete & 83 & 27.3 \\
\hline College education complete or incomplete & 13 & 4.3 \\
\hline \multicolumn{3}{|l|}{ Employment status ( $\mathrm{n}=307$ ) } \\
\hline With activity (employed, self-employed, retired) & 112 & 36.5 \\
\hline No activity (unemployed, retired) & 195 & 63.5 \\
\hline \multicolumn{3}{|l|}{ Income* $(n=303)$} \\
\hline Equal to or less than 3 minimum wages & 270 & 89.1 \\
\hline More than 3 minimum wages & 33 & 10.9 \\
\hline \multicolumn{3}{|l|}{ City of residence $(n=308)$} \\
\hline Salvador & 248 & 80.5 \\
\hline Other cities & 60 & 19.5 \\
\hline
\end{tabular}

Table 2 - CVA clinical manifestations at the time of stroke, National Institute of Health Stroke Scale score, time of arrival, previous healthcare service, thrombolysis, and admission to the Stroke Comprehensive Care Unit of study participants, Salvador, Bahia, Brazil, 2020

\begin{tabular}{lcc}
\hline & \multicolumn{2}{c}{ Sample } \\
Variables & (n= 308) \\
& $\mathbf{n}$ & \% \\
\hline Clinical manifestation of ischemic stroke* & & \\
Paresis & 256 & 83.1 \\
Dysarthria & 222 & 72.1 \\
Dizziness and imbalance & 183 & 59.4 \\
Lip commissure deviation & 178 & 57.8 \\
Aphasia & 123 & 39.9 \\
Headache & 97 & 31.5 \\
Double vision and/or difficulty seeing & 68 & 22.1 \\
Nausea & 51 & 12.0 \\
Dyspnea & 49 & 15.9 \\
Dysphagia & 45 & 14.6 \\
Syncope & 44 & 14.3 \\
Relaxation of sphincters & 44 & 14.3 \\
Vomiting & 37 & 12.0 \\
Other symptoms & 91 & 29.5 \\
National Institute of Health Stroke Scale (Mean $=10.7 ; S D=7.2)$ & & \\
×5 & 66 & 21.4 \\
6-13 & 110 & 35.7 \\
$\geq 14$ & 79 & 25.6 \\
No information in the medical record & 53 & 17.2 \\
Previous healthcare service & & \\
Straight to the referral hospital & 47 & 15.3 \\
Mobile Emergency Care Service & 84 & 27.3 \\
Other health service & 177 & 57.4 \\
\hline & To be continued \\
&
\end{tabular}




\begin{tabular}{|c|c|c|}
\hline \multirow[t]{2}{*}{ Variables } & \multicolumn{2}{|c|}{$\begin{array}{c}\text { Sample } \\
(n=308)\end{array}$} \\
\hline & $\mathbf{n}$ & $\%$ \\
\hline \multicolumn{3}{|l|}{ Time to arrive at the study institution } \\
\hline$\leq 3$ hours & 125 & 40.6 \\
\hline$>3$ hours to $\leq 4,5$ hours & 55 & 17.9 \\
\hline$>4.5$ hours to $\leq 24$ hours & 58 & 18.8 \\
\hline$>24$ hours to $\leq 72$ hours & 40 & 13.0 \\
\hline$>72$ hours & 30 & 9.7 \\
\hline Venous thrombolysis & 80 & 26.0 \\
\hline Admission to the Stroke Comprehensive Care Unit & 221 & 71.8 \\
\hline
\end{tabular}

Regarding the clinical manifestation of stroke, the most frequent signs and symptoms were paresis (83.1\%), dysarthria (72.1\%), dizziness and imbalance (58.5\%), and lip commissure deviation (57.8\%). Approximately $30 \%$ of the sample described other symptoms, which included seizures, tremors, and eye pain. The mean NIHSS score was $10.7(S D=7.2)$. A greater proportion of participants scored from 6 to 13 (35.7\%), followed by those with scores above 14 (25.6\%). However, $17.2 \%$ had no information of this assessment in their medical records.

Concerning the services sought, only $14.9 \%$ of the participants went directly to the institution studied after the onset of symptoms. Even so, most of the sample arrived at the referral hospital within 4.5 hours of symptom onset (57.9\%). However, only $26 \%$ underwent venous thrombolysis. Regarding hospitalization at the studied institution, most of the sample was hospitalized at the UAVC (71.8\%) at some point during the hospital stay.

\section{Length of hospital stay, mortality and disability up to 90 days after stroke}

The length of stay ranged from 1 to 117 days with a median of 11 days. From the total, $25 \%$ of the participants were hospitalized for up to 7 days and $75 \%$ for up to 19 days.

Of the 308 participants, 259 (84.1\%) were discharged, 11 (3.6\%) were transferred to another hospital, and 38 (12.3\%) died during hospitalization. As for mortality up to 90 days after stroke, 21 new deaths were observed after discharge, making a total of 59 . Considering the lack of follow-up of nine participants due to the impossibility of contacting them, the cohort sample consisted of 299 people. Thus, the 59 deaths represented 19.7\%.

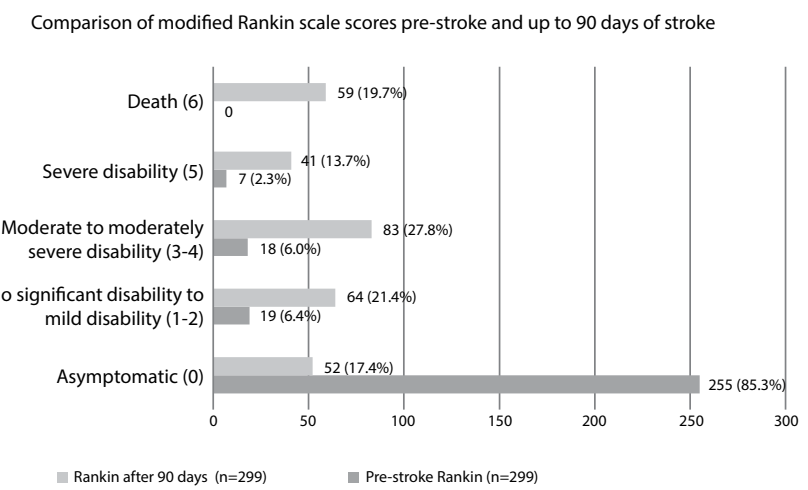

Figure 1 - Comparison of modified Rankin scale scores pre-stroke and up to 90 days after the stroke, Salvador, Bahia, Brazil 2020
The comparison between the pre-morbid Rankin with the Rankin after 90 days $(n=299)$ also showed that, after the CVAi, there was a greater proportion of people in the classes with greater functional disability $(41.5 \%)$, represented by those with moderate to severe disabilities $(p=0.117)$. It is noteworthy that, of the $85.3 \%$ participants who were asymptomatic before the CVA, only $17.4 \%$ remained without sequelae.

\section{DISCUSSION}

This study showed that strokes affected the male and female population in similar proportions, mostly elderly, non-white, without a partner, with low income and low educational level. These findings agree to two studies carried out in Salvador ${ }^{(16,18)}$, one in Paraíba ${ }^{(26)}$, and another in Roraima ${ }^{(8)}$, all from the Northeast and North regions of the country. Two studies from the South Region also showed similar results in terms of mean age and non-predominance of gender, but they did not describe other social characteristics such as race/color, educational level and income ${ }^{(14,27)}$. With different results, Pinto et al. ${ }^{(19)}$ observed younger people affected by stroke in Salvador, with a mean age of 55.8 years $(S D=13.3)$, noting that, in this study, the public was recruited in a follow-up clinic.

People without employment and residents of the state capital were more prevalent, results that coincide with those of the study carried out in Roraima ${ }^{(8)}$ but were not identified in the investigations in Salvador ${ }^{(16,18)}$. Diverging from the present study, investigations in the Southeast region showed a predominance of males in a study carried out in the Triângulo Mineiro(15) and females in a study in São Paulo ${ }^{(28)}$; in relation to race/color, the majority of white participants were found in both. Some international articles showed a higher mean age and a predominance of males ${ }^{(0,29-31)}$, however, like the studies from the South of the country, they did not assess the level of education or income of the samples, making the comparison between these variables unfeasible.

As for comorbidities, systemic arterial hypertension was the most frequent, reiterating that it is the main risk factor for cerebrovascular diseases as indicated by the Brazilian Guidelines on Arterial Hypertension and endovascular treatments for stroke ${ }^{(32-33)}$ and by epidemiological studies ${ }^{(2-3,3,1,16,18,27,34)}$. Other risk factors, such as dyslipidemia, diabetes mellitus and atrial fibrillation have also been referenced ${ }^{(2-3,10,16,18,34)}$, as well as previous ischemic events ${ }^{(3,14)}$. More than $40 \%$ of participants in this study smoked or had smoked. Smoking is another risk factor increasingly highlighted in discussions on preventive actions against strokes ${ }^{(3)}$, thus, encouraging the strengthening of combat programs $s^{(17)}$.

Knowledge of risk factors for strokes in different population groups is essential for developed and developing countries to design primary prevention strategies specific to their populations. The risk factors identified in the participants of this study are widely discussed in literature, and it is worth noting that the contribution of high systolic blood pressure to years of life lost due to disability in Latin American countries is greater than in high-income countries ${ }^{(17)}$. Therefore, hypertension deserves special attention when planning prevention and health care actions.

As for the characterization of the clinical condition of the participants, the mean NIHSS score was 10.7 (SD = 7.2), demonstrating a moderate severity of strokes. This result was similar to those found 
in several studies ${ }^{(8-9,18,29)}$ and slightly higher than that shown in others ${ }^{(16,27)}$. The most frequent signs and symptoms were paresis, dysarthria, dizziness and imbalance, and lip commissure deviation. Despite being highlighted in classic literature ${ }^{(35)}$, they are seldom described in recent studies, not allowing further discussions.

More than half of the sample reached the study location within 4.5 hours - that is, within the therapeutic window for thrombolysis - but only $26 \%$ of people underwent this therapy. Although a significant portion did not underwent the procedure, the prevalence of thrombolysis in this study was higher than that shown in others ${ }^{(14-15,36-37)}$ and is similar to the one reported in an investigation in England ${ }^{(38)}$ and in another study in the same location as this one ${ }^{(18)}$. The non-performance of the treatment in a portion of the people who arrived within the therapeutic window can be explained by illegibility, but it can also be related to professional failures, such as the inability to immediately recognize the stroke, the lack of activation of the specialized unit team, and the delay in neuroimaging exams.

Recent studies have suggested extending the thrombolytic therapeutic window to nine hours after the onset of symptoms, depending on strict eligibility criteria and advanced neuroimaging tests ${ }^{(28)}$, but national and international guidelines still maintain the recommendation of infusion of therapy in the first four hours and 30 minutes. Ensuring the benefits of intravenous thrombolysis demands the ability of the victim and the people around them to recognize the signs and symptoms early and immediately seek a health service. In addition, a pre- and intra-hospital service network capable of meeting the demand is essential, which includes partnerships between the various services, implementation of specialized units, and permanent professional training.

Regarding previous care in health services, only $14.9 \%$ of the participants went directly to the study locus in the presence of symptoms, and the activation of the Mobile Emergency Care Service was made by less than $30 \%$ of the entire sample. This may have occurred due to the lack of information of the participants and companions about the urgent characteristic of the event and about the network services with better availability of resources for care ${ }^{(39-40)}$. Kim et al. ${ }^{(37)}$ verified that people with strokes admitted to hospitals and coming from emergency services such as the SAMU (a mobile emergency attention service) had less access time to neuroimaging and received thrombolytic therapy more frequently. A national survey found that all Brazilian states that had more than $80 \%$ of the population covered by the SAMU showed a decline in mortality and hospitalization due to stroke ${ }^{(41)}$. Prompt and qualified care for people with stroke through well-defined and detailed flows and procedures is essential to ensure survival and a good prognosis ${ }^{(42)}$.

Concerning the units at the institution studied, most of the sample was admitted to the specialized unit at some point during their hospital stay. The benefits in reducing the absolute risk of death or dependence ${ }^{(43-44)}$ have been observed when comparing hospitalization in UAVC and other units. In addition, authors ${ }^{(45)}$ emphasize that the specific unit for assistance to people with acute stroke adds physical structure and differentiated equipment and the specialized team provides more effective and faster care, with more benefits and better conditions at discharge.

The length of stay ranged from 1 to 117 days, with a median of 11 days. These findings are similar to those presented in the literature regarding the average length of stay ${ }^{(45-46)}$. The few Brazilian studies that evaluated the influence of factors on length of stay highlighted in-hospital complications such as pneumonia and urinary tract infection as the main causes of longer hospital stays ${ }^{(8,47)}$.

The vast majority of patients were discharged. Considering the sum of in-hospital deaths and those occurring within 90 days after stroke, almost $20 \%$ of the sample died. The comparison of pre-morbid Rankin with Rankin after 90 days of stroke showed that a relevant percentage of the sample (45.3\%) migrated from asymptomatic, without significant disability and mild disability to moderate to severe disability, although without statistical significance. Less than $20 \%$ of the sample remained without sequelae in the 90 days after the event. From a clinical point of view, this percentage is extremely relevant and above statistical significance considering the impact of moderate to severe disability in the lives of these people, which goes from independence to dependence on home care. The high mortality and the significant increase in people with moderate to severe degrees of disability after stroke corroborate other studies ${ }^{(29,48)}$, which also reiterate the clinical and social significance of the impacts of this event. In addition to early deaths, hospital and social security costs, the loss of autonomy among adults and their consequent dependence are other signs of the severity of the stroke and the disabilities that may result from it, especially since they reduce the active and productive force of society ${ }^{(8)}$. Authors highlight stroke as one of the main reasons for the high mortality rates in the Northeast region ${ }^{(7)}$. Considering the regional differences and the impact of this disease ${ }^{(17)}$, it is necessary to produce knowledge to understand and help people in this state of disability, as well as those around them, since it is a complex condition, which is linked to significant changes in daily life that need to have adaptations in all areas ${ }^{(49)}$.

This epidemiological panorama expresses the need to implement effective strategies to prevent ischemic events, identify and control risk factors, as well as to enable and optimize the institution of time-dependent therapies to minimize disabilities and mortality from the ischemic event. To this end, community health education guided by social, economic, demographic, and clinical characteristics can empower individuals for health care, recognition of the signs and symptoms of the event, as well as identification of the health service to be sought in their region. The significant disability 90 days after the event found in this study also revealed the need for the family to be prepared to care for its member at home and for the health system to offer support in rehabilitation.

\section{Study limitations}

The study was carried out in a single hospital in the state of Bahia, which is part of the public network and is a reference for the care of people with CVA, that is, the establishment has specific characteristics, which prevents the generalization of the results.

\section{Contributions to Nursing and Public Health}

In addition to regional and socioeconomic issues, the determining conditions for stroke and, consequently, for high morbidity and mortality are linked to risk factors and to preventable and controllable factors. Knowing the profile of people assisted in a reference service 
in the state can help in the early identification of these factors and in the planning of educational actions, as well as nursing care and rehabilitation aimed at preventing and controlling stroke complications, according to the particularities of the people assisted.

\section{CONCLUSIONS}

The study characterized people with CVA who were admitted to a public hospital of reference in neurology, in Salvador, Bahia. There was no gender predominance, most of the sample was elderly, without a partner, with low income and educational level, inactive in terms of employment, resident in the capital, and hypertensive. Regarding the clinical variables, the average NIHSS score suggested moderate severity, and the participants presented the typical signs and symptoms of a stroke. Most of them arrived at the referral service within the therapeutic timeframe, but less than a third went through thrombolytic therapy. The services sought to start attention were found to be inadequate. As for the comparison between the modified Rankin Scale pre-stroke and after 90 days, high mortality and disability were observed.

These findings contribute to the development of nursing health education actions aimed at preventing the event with a focus on modifiable risk factors. Furthermore, they can guide managers in the organization of services aimed at people who have suffered strokes, highlighting the importance of nursing care in the acute phase of the disease and in rehabilitation, according to the specificities of the population investigated.

\section{ACKNOWLEDGMENT}

Acknowledgments to the data collection team, composed of undergraduate nursing students Alexandra Bahia Mendonça Barreto, Greice Alves Costa, Larissa Vitória Pereira, Letícia Melquiades Nascimento, Rilary Silva Sales and Tatiana de Sena Leitão.

\section{REFERENCES}

1. Paley L, Williamson E, Bray BD, Hoffman A, James MA, Rudd AG, et al. Associations between 30-day mortality, specialist nursing, and daily physician ward rounds in a national stroke registry. stroke. 2018;49(9):2155-62. https://doi.org/10.1161/STROKEAHA.118.021518

2. Vos T, Lim SS, Abbafati C, Abbas KM, Abbasi M, Abbasifard M, et al. Global burden of 369 diseases and injuries in 204 countries and territories, 1990-2019: a systematic analysis for the Global Burden of Disease Study 2019. Lancet. 2020;396(10258):1204-22. https://doi. org/10.1016/S0140-6736(20)30925-9

3. Oliveira GMM, Brant LCC, Polanczyk CA, Biolo A, Nascimento BR, Malta DC, et al. Cardiovascular Statistics - Brazil 2020. Arq Bras Cardiol. 2020 Sep 18;115(3):308-439. https://doi.org/10.36660/abc.20200812

4. Gonçalves JL, Feitosa ES, Borges RT. [Epidemiological profile of stroke victims in a reference hospital in Ceará/Brazil]. Rev Interd [Internet]. 2019 [cited 2020 Dec 5];12(2):92-103. Available from: https://revistainterdisciplinar.uninovafapi.edu.br/index.php/revinter/article/ view/1219/pdf_426 Portuguese.

5. Cardoso SG, Lavigne PED, Queiroz RMT de, Lavigne JVD, Vasconcelos VB. [Epidemiological profile of patients hospitalized as a matter of urgency in the city of Salvador - BA]. Prevenção e Promoção de Saúde 3 [Internet]. 2019 [cited 2020 Dec 5]. p. 169-76. Available from: https://www.finersistemas.com/atenaeditora/index.php/admin/api/artigoPDF/26084 Portuguese.

6. Carvalho VP, Leonardo H, Ribeiro S. [Clinical-epidemiological profile of stroke patients]. Rev Saúde Desenvolv [Internet]. 2019 [cited 2020 Dec 10];13(15):50-6. Available from: https://www.uninter.com/revistasaude/index.php/saudeDesenvolvimento/article/view/1059 Portuguese.

7. Souza Júnior EV, Jesus MAS, Bezerra CLS, Rosa RRS, Boery EN, Boery RNSO. Mortality rate for cerebral infarction in the macro region southwest of the State of Bahia, Brazil. Enferm Actual Costa Rica [Internet]. 2018 [cited 2020 Nov 24];18:1-13. Available from: https://www. researchgate.net/publication/325500244_Mortality_rate_for_cerebral_infarction_in_the_macro_region_southwest_of_the_State_of_ Bahia_Brazil

8. Fonseca ARR, Murari RSW, Fonseca AJ, Buenafuentes SMF. Socioeconomic impact of stroke in the state of Roraima: in a hospital-based cohort study.Rev Bras Neurol Psiquiatr [Internet]. 2018 [cited 2020 Dec 4];22(2):124-41. Available from: https://rbnp.emnuvens.com.br/ rbnp/article/view/215/0

9. Hacke W, Kaste M, Bluhmki E, Brozman M, Dávalos A, Guidetti D, et al. Thrombolysis with Alteplase 3 to 4.5 Hours after Acute Ischemic Stroke. N Engl J Med. 2008;359(13):1317-29. https://doi.org/10.1056/NEJMoa0804656

10. Gumprecht J, Domek M, Hill AM, Lip GYH. Avoiding Stroke: Avoiding Stroke: A Continuous Monitoring Challenge. Cerebrovasc Dis. 2020;49(2):121-3. https://doi.org/10.1159/000506680

11. Rodrigues MDS, Santana LF, Galvão IM. Modifiable and non-modifiable risk factors of ischemic stroke: a descriptive approach. Rev Med. 2017;96(3):187. https://doi.org/10.11606/issn.1679-9836.v96i3p187-192

12. Mourão AM, Vicente LCC, Chaves TS, Sant'Anna RV, Meira FC, Xavier RMB, et al. Profile of patients diagnosed with stroke treated at a hospital in Minas Gerais accredited in the Care Line. Rev Bras Neurol [Internet]. 2017 [cited 2020 Dec 6];53(4):12-6. Available from: https://revistas. ufrj.br/index.php/rbn/article/view/14634

13. Yamashita LF, Fukujima MM, Granitoff N, Prado GF. [Patients with ischemic stroke are taken care quickly in São Paulo Hospital]. Arq Neuropsiquiatr. 2004 Mar;62(1):96-102. https://doi.org/10.1590/S0004-282X2004000100017 Portuguese. 
14. Barella RP, Duran VAA, Pires AJ, Duarte RO. [Profile of the care of patients with stroke in a philanthropic hospital Of Southern Santa Catarina and Feasibility Study for Implantation of the Stroke Unit]. Arq Catarinenses Med [Internet]. 2019 [cited 2020 Dec 5];48(1):131-43. Available from: http://www.acm.org.br/acm/seer/index.php/arquivos/article/view/432/334 Portuguese.

15. Nascimento KG, Chavaglia SRR, Pires PS, Ribeiro SBF, Barbosa MH. Clinical outcomes of ischemic stroke patients after thrombolytic therapy. Acta Paul Enferm. 2016;29(6):650-7. https://doi.org/10.1590/1982-0194201600091

16. Matos I, Fernandes A, Maso I, Oliveira-Filho J, Jesus PA, Fraga-Maia $\mathrm{H}$, et al. Investigating predictors of community integration in individuals after stroke in a residential setting: a longitutinal study. PLoS One. 2020;15(5):e0233015. https://doi.org/10.1371/journal.pone.0233015

17. Ouriques Martins SC, Sacks C, Hacke W, Brainin M, Assis Figueiredo F, Marques Pontes-Neto O, et al. Priorities to reduce the burden of stroke in Latin American countries. Lancet Neurol. 2019;18(7):674-83. https://doi.org/10.1016/S1474-4422(19)30068-7

18. Maso I, Pinto EB, Monteiro M, Makhoul M, Mendel T, Jesus PAP, et al. A simple hospital mobility scale for acute ischemic stroke patients predicts long-term functional outcome. neurorehabil neural repair. 2019;33(8):614-22. https://doi.org/10.1177/1545968319856894

19. Pinto EB, Nascimento C, Monteiro M, Castro M, Maso I, Campos A, et al. Proposal for a New Predictive Scale for Recurrent Risk of Fall in a Cohort of Community-Dwelling Patients with Stroke. J Stroke Cerebrovasc Dis. 2016;25(11):2619-26. https://doi.org/10.1016/j. jstrokecerebrovasdis.2016.06.045

20. Conselho Nacional de Saúde. Resolução n 580, de 22 de março de 2018 [Internet]. 2018 [cited 2020 Dec 5];135;55. Available from: http:// www.conselho.saude.gov.br/resolucoes/2018/Reso580.pdf

21. Conselho Nacional de Saúde. Resolução no 466, de 12 de dezembro de 2012 [Internet]. 2012 [cited 2020 Dec 5]; 12;59. Available from: https://conselho.saude.gov.br/resolucoes/2012/Reso466.pdf

22. Ministério da Saúde (BR). Portaria no 2.856, de 17 de dezembro de 2012 [Internet]. 2012 [cited 2020 Dec 5]. Available from: http://bvsms. saude.gov.br/bvs/saudelegis/gm/2012/prt2856_17_12_2012.html

23. Von Elm E, Altman DG, Egger M. The Strengthening the Reporting of Observational Studies in Epidemiology (STROBE) statement: guidelines for reporting observational studies. BMJ. 2007;370(9596):1453-7. https://doi.org/10.1136/bmj.39386.490150.94

24. Brito R, Lins L, Almeida C, Ramos-Neto E, Araújo D, Franco C. [Specific Functional Assessment Instruments for Stroke]. Rev Neurociências. 2014 Feb 5;21(04):593-9. https://doi.org/10.4181/RNC.2013.21.850.7p Portuguese.

25. Baggio JAO, Santos-Pontelli TEG, Cougo-Pinto PT, Camilo M, Silva NF, Antunes P, et al. Validation of a Structured Interview for Telephone Assessment of the Modified Rankin Scale in Brazilian Stroke Patients. Cerebrovasc Dis. 2014;38(4):297-301. https://doi. org/10.1159/000367646

26. Trigueiro ACQ, Gagliardi RJ. [Clinical and functional profile of patients suffered by vascular cerebral accident, in Patos-PB]. Temas Saúde [Internet]. 2019 [cited 2020 Dec 6];19(1):86-100. Available from: http://temasemsaude.com/wp-content/uploads/2019/01/19106.pdf Portuguese.

27. Gaspari AP, Cruz EDA, Batista J, Alpendre FT, Zétola V, Lange MC. Predictors of prolonged hospital stay in a comprehensive stroke unit. Rev Latino-Am Enfermagem. 2019;27. https://doi.org/10.1590/1518-8345.3118.3197

28. Goulart AC. "EMMA Study: a Brazilian community-based cohort study of stroke mortality and morbidity." Sao Paulo Med J. 2016;134(6):54354. https://doi.org/10.1590/1516-3180.2016.024227092016

29. Ma H, Campbell BCV, Parsons MW, Churilov L, Levi CR, Hsu C, et al. Thrombolysis Guided by Perfusion Imaging up to 9 Hours after Onset of Stroke. N Engl J Med. 2019;380(19):1795-803. https://doi.org/10.1056/NEJMoa1813046

30. Fraticelli L, Freyssenge J, Claustre C, Buisson M, Bischoff M, Nighoghossian N, et al. Sex-related differences in management and outcome of acute ischemic stroke in eligible patients to thrombolysis. Cerebrovasc Dis. 2019;47(3-4):196-204. https://doi.org/10.1159/000500901

31. Purroy F, Vena A, Forné C, Arce AM, Dávalos A, Fuentes B, et al. Age-and Sex-Specific Risk Profiles and In-Hospital Mortality in 13,932 Spanish Stroke Patients. Cerebrovasc Dis. 2019;47(3-4):151-64. https://doi.org/10.1159/000500205

32. Malachias M, Souza W, Plavnik F, Rodrigues C, Brandão A, Neves M, et al. 7th Brazilian Guideline of Arterial Hypertension: Chapter 1 Concept, Epidemiology and Primary Prevention. Arq Bras Cardiol. 2016;107(3):306. https://doi.org/10.5935/abc.20160151

33. Pontes-Neto OM, Cougo P, Martins SCO, Abud DG, Nogueira RG, Miranda M, et al. Brazilian guidelines for endovascular treatment of patients with acute ischemic stroke. Arq Neuropsiquiatr. 2017;75(1):50-6. https://doi.org/10.1590/0004-282X20160174

34. O'Donnell MJ, Chin SL, Rangarajan S, Xavier D, Liu L, Zhang H, et al. Global and regional effects of potentially modifiable risk factors associated with acute stroke in 32 countries (INTERSTROKE):a case-control study. Lancet. 2016;388(10046):761-75. https://doi.org/10.1016/ S0140-6736(16)30506-2

35. Powers WJ, Rabinstein AA, Ackerson T, Adeoye OM, Bambakidis NC, Becker K, et al. 2018 Guidelines for the Early Management of Patients With Acute Ischemic Stroke: a guideline for healthcare professionals from the American Heart Association/American Stroke Association. Stroke. 2018;49(3):46-110. https://doi.org/10.1161/STR.0000000000000158

36. Fonseca LHO, Rosa MLG, Silva AC, Maciel RM, Volschan A, Mesquita ET. Analysis of barriers to the use of thrombolytics in ischemic stroke in a private hospital in Rio de Janeiro, Brazil. Cad Saude Publica. 2013 Dec;29(12):2487-96. https://doi.org/10.1590/0102-311x00131412

37. Kim DH, Nah HW, Park HS, Choi JH, Kang MJ, Huh JT, et al. Impact of prehospital intervention on delay time to thrombolytic therapy in a stroke center with a systemized stroke code program. J Stroke Cerebrovasc Dis. 2016;25(7):1665-70. https://doi.org/10.1016/j. jstrokecerebrovasdis.2016.02.011 
38. Grunwald IQ, Phillips DJ, Sexby D, Wagner V, Lesmeister M, Bachhuber M, et al. Mobile stroke unit in the uk healthcare system: avoidance of unnecessary accident and emergency admissions. Cerebrovasc Dis. 2020;49(4):388-95. https://doi.org/10.1159/000508910

39. Pitton Rissardo J, Fornari Caprara AL, Cervi Prado AL. Stroke Literacy in a South Brazilian City: A Community Based Survey. J Stroke Cerebrovasc Dis. 2018;27(9):2513-8. https://doi.org/10.1016/j.jstrokecerebrovasdis.2018.05.006

40. Panício MI, Mateus L, Ricarte IF, Figueiredo MM, Fukuda TG, Seixas JC, et al. The influence of patient's knowledge about stroke in Brazil: a cross sectional study. Arq Neuropsiquiatr. 2014;72(12):938-41. https://doi.org/10.1590/0004-282X20140167

41. Lopes JM, Sanchis GJB, Medeiros JLA, Dantas FG. Hospitalization for ischemic stroke in Brazil: an ecological study on the possible impact of Hiperdia. Rev Bras Epidemiol. 2016;19(1):122-34. https://doi.org/10.1590/1980-5497201600010011

42. Ministério da Saúde (BR). Manual de rotinas para atenção ao AVC[Internet]. 2013 [cited 2020 Dec 4];5-48. Available from: http://bvsms. saude.gov.br/bvs/publicacoes/manual_rotinas_para_atencao_avc.pdf

43. Rocha MSG, Almeida ACF, Abath Neto O, Porto MPR, Brucki SMD. Impact of stroke unit in a public hospital on length of hospitalization and rate of early mortality of ischemic stroke patients. Arq Neuropsiquiatr. 2013;71(10):774-9. https://doi.org/10.1590/0004-282X20130120

44. Baptista SCPD, Juliani CMCM, Olbrich SRLR, Braga GP, Bazan R, Spiri WC. Evaluation of death indicators and disability of patients attended in a stroke unit. Texto Context Enferm. 2018;27(2):1-9. https://doi.org/10.1590/0104-070720180001930016

45. Vieira LGDR, Safanelli J, Araujo T, Schuch HA, Kuhlhoff MHR, Nagel V, et al. The cost of stroke in private hospitals in Brazil: a one-year prospective study. Arq Neuropsiquiatr. 2019;77(6):393-403. https://doi.org/10.1590/0004-282x20190056

46. Almeida LG, Vianna JBM. Epidemiology of patients hospitalized for stroke in a teaching hospital. Rev Ciênc Saúde. 2018;8(1):12-7. https:// doi.org/10.21876/rcsfmit.v8i1.741

47. Paulo RB, Guimarães TM, Helito PVP, Marchiori PE, Yamamoto FI, Mansur LL, et al. [Stroke in a neurology ward: etiologies, complications and length of stay. Rev Assoc Med Bras. 2009;55(3):313-6. https://doi.org/10.1590/S0104-42302009000300025

48. Oliveira SG, Gotto JRF, Spaziani AO, Frota RS, Souza MAG, Freitas CJ, et al. Diseases of the circulatory device in Brazil according to Datasus: a study from 2013 to 2018. Braz J Health Rev. 2020;3(1):832-46. https://doi.org/10.34119/bjhrv3n1-066

49. Teixeira CP, Silva LD. [The Physical Disabilities Of Stroke Patients: Nursing Actions]. Enferm Glob [Internet]. 2009 [cited 2020 Dec 6];15:1-12. Available from: http://scielo.isciii.es/pdf/eg/n15/pt_revision1.pdf Portuguese. 